Vol. 1 , No. 1 , Januari 2019

\title{
HUBUNGAN ASUPAN ZAT GIZI MAKRO DARI SARAPAN DENGAN STATUS GIZI SISWA
}

\section{RELATIONSHIP OF INTEGRATED MACRO NUTRITION FROM BREAKFAST WITH STUDENT NUTRITION STATUS}

\author{
Sunarto Kadir \\ Fakultas Olahraga dan Kesehatan, Univeristas Negeri Gorontalo \\ E-mail : sunarto.kadir@yahoo.co.id
}

\begin{abstract}
Abstrak
Asupan zat gizi makro (karbohidrat, protein, dan lemak) yang berasal dari sarapan adalah komponen utama penghasil energi yang berperan penting dalam meningkatkan keadaan status gizi siswa. Penelitian ini dilakukan pada siswa di MTs Negeri 1 Kota Gorontalo. Tujuan penelitian adalah untuk menganalisis hubungan antara asupan zat gizi makro dengan status gizi siswa. Jenis penelitian yang digunakan adalah survei analitik dengan rancangan cross sectional. Populasi dalam penelitian ini adalah seluruh siswa kelas VIII di MTs Negeri 1 Kota Gorontalo dengan jumlah 384 orang. Sampel diperoleh sebanyak 196 orang yang diambil dengan menggunakan teknik purposive sampling. Data asupan karbohidrat, protein, dan lemak dikumpul menggunakan angket food recall 24 jam, sedangkan data status gizi siswa dikumpul melalui pengukuran tinggi badan dan berat badan. Analisis data menggunakan uji korelasi Spearman Rank.Hasil penelitian menunjukkan bahwa ada hubungan yang signifikan antara asupan zat gizi makro (karbohidrat $\mathrm{p}=0,000$; protein $\mathrm{p}=0,000$; lemak $\mathrm{p}=0,000$ ) dari sarapan dengan status gizi siswa di MTs Negeri 1 Kota Gorontalo. Disarankan kepada siswa agar selalu memperhatikan asupan gizi dari makanan yang dikonsumsi sehingga dapat mempertahankan keadaan status gizi yang optimal.
\end{abstract}

Kata kunci : Asupan; Status gizi; Zat gizi makro

\begin{abstract}
Intake of macronutrients (carbohydrates, proteins and fats) derived from breakfast are the main components of energy producers that play an important role in improving the state of nutritional status of students. This research was conducted on students at MTs Negeri 1 Kota Gorontalo. The aim of the research was to analyze the relationship between the intake of macronutrients and the nutritional status of students. The type of research used is analytic survey with cross sectional design. The population involved all of the students in grade VIII at MTs Negeri 1 Kota Gorontaloas many as 384 adolescents. The sample was 196 people taken by using purposive sampling technique. Data of carbohydrate, protein and fat intake were collected using 24-hour food recall questionnaire, while data on nutritional status of students were collected through measurements of height and weight. Data analysis using Spearman Rank correlation test. The results showed that there was a significant relationship between the intake of macronutrients (carbohydrate $p=0.000$; protein $p=0.000$; fat $p=0.000$ ) from breakfast and the nutritional status of students at MTs Negeri 1 Kota Gorontalo. It is recommended that the students should be aware of the food nutritional intake consumed so that they are able to maintain the nutritional status optimally.
\end{abstract}

Keywords: Intake; Macronutrients; Nutritional status

(C) 2019- Sunarto Kadir Under the license CC BY-SA 4.0 
Vol. 1 , No. 1 , Januari 2019

\section{PENDAHULUAN}

Masalah gizi yang utama dialami oleh para remaja diantaranya yaitu kelebihan berat badan/obesitas, kekurangan zat gizi, dan anemia defisiensi zat besi ${ }^{1}$. Menurut data Laporan Riset Kesehatan Dasar tahun 2013, secara nasional status gizi anak remaja pada usia 13-15 tahun belum ada perubahan angka persentasinya. Prevalensi kependekan (TB/U) pada remaja usia 13-15 tahun yaitu $35,1 \%$. Serta prevalensi status gizi (IMT/U), persentasi kekurusan pada remaja usia 13-15 tahun yaitu sebanyak $11 \%$ dan persentasi kegemukan sebanyak $10,8 \%{ }^{2}$.

Salah satu penyebab rendahnya asupan zat gizi pada anak adalah kebiasaan makan. Sepertiga dari pemenuhan angka kecukupan gizi diperoleh dari makan pagi. Di Indonesia masih banyak anak yang tidak terbiasa ataupun melewatkan waktu sarapan, sedangkan yang sering sarapan mutu sarapannya masih rendah. Berdasarkan Riset Kesehatan Dasar 2010, 16,9\%-50\% anak usia sekolah dan remaja, serta rata-rata $31,2 \%$ orang dewasa tidak biasa sarapan. Anak sekolah mengkonsumsi minuman saat sarapan $(26,1 \%)$, seperti air putih susu, atau teh dan 44,6\% mengkonsumsi sarapan berkualitas rendah $^{3}$. Melewatkan sarapan ataupun konsumsi sarapan yang tidak memadai dapat menyebabkan defisit zat gizi. Ketidakcukupan zat gizi karena kehilangan nutrisi yang ditimbulkannya jarang dapat dipenuhi oleh konsumsi makanan di waktu lain. Sarapan dapat memberikan dampak positif pada status nutrisi ${ }^{4}$.

Sarapan dapat menyediakan zat-zat gizi yang diperlukan oleh tubuh, diantaranya zat gizi makro yakni karbohidrat, protein dan lemak Zat gizi tersebut merupakan penghasil energi, meningkatkan pertumbuhan, dan berperan dalam metabolisme. Selain itu berperan dalam fungsi kerja otak yang menyediakan kadar glukosa bagi otak, serta sebagai alat transportasi aktif untuk otak ${ }^{5}$.

Siswa MTs adalah siswa yang duduk atau sedang menutut ilmu di bangku sekolah menengah pertama. Siswa kelas VIII ditingkat MTsdigambarkan sebagai siswa yang tergolong usia labil dengan rentang usia 12,5-13,5 tahun, yang disebut remaja awal. Pada tahap ini merupakan tahap transisi untuk mulai mengenal satu sama lain, mengetahui keadaan sekolah dan mulai berani menunjukan sikap. Mereka cenderung lebih memanfaatkan lingkungan diluar rumah termasuk sekolah untuk mencari makanan kesukaan. Terpaparnya anak-anak ini dengan lingkungan, budaya, dan teman sebaya membuat mereka memiliki keputusan sendiri dalam berperilaku memilih makanan. Salah satunya adalah dalam memilih makanan yang di konsumsinya saat sarapan.

MTs Negeri 1 Kota Gorontalo merupakan salah satu sekolah unggulan di Kota Gorontalo yang telah menerapkan ilmu gizi pada pelajaran muatan lokal.Berdasarkan observasi awal pada siswa kelas VIII MTs Negeri 1 Kota Gorontalo pada bulan Agustus 2017 bahwa proporsi status gizi siswa diperoleh kekurusan sebesar 38,9\% (22,2\% kurus tingkat berat dan 16,7\% kurus tingkat ringan), $36,8 \%$ normal, dan 24,3\% kegemukan (7,9\% kelebihan berat badan tingkat ringan, $11,1 \%$ obesitas tingkat I, serta 5,3\% obesitas tingkat II). Dari 60 siswa kelas VIII MTs Negeri 1 Kota Gorontalo diperoleh 18 siswa $(30,0 \%)$ tidak pernah melakukan sarapan. Berdasarkan uraian tersebut, maka perlu dilakukan penelitian untuk menganalisis hubungan antara asupan zat gizi makro dengan status gizi siswa di MTs Negeri 1 Kota Gorontalo.

\section{METODE PENELITIAN}

Penelitian ini dilakukan di MTs Negeri 1 Kota Gorontalo, yakni pada bulan November sampai dengan Desember 2017. Jenis penelitian yang digunakan adalah survey analitik dengan rancangan cross sectional, untuk menganalisis hubungan antara asupan zat gizi makro dengan status gizi siswa. Populasi dalam penelitian ini adalah seluruh siswa kelas VIII MTs Negeri 1 Kota Gorontalo yaitu sebanyak 383 orang. Sampel kemudian diperoleh sebanyak 196 orang yang diambil dengan menggunakan teknik purposive sampling, yaitu pengambilan sampel didasarkan atas pertimbangan tertentu yang dibuat oleh peneliti, berdasarkan ciri atau sifat-sifat populasi yang sudah diketahui 
Vol. 1 , No. 1 , Januari 2019

sebelumnya. Data dianalisis menggunakan uji korelasi Spearman Rank, dengan bantuan program SPSS.

3. HASIL DAN PEMBAHASAN

a. Hasil Penelitian

1) Asupan Zat Gizi Makro dari Sarapan

Tabel 1 Distribusi Responden Berdasarkan Asupan Zat Gizi Makro dari Sarapan

\begin{tabular}{|c|c|c|}
\hline Asupan Zat Gizi Makro dari Sarapan & $\mathrm{n}$ & $\%$ \\
\hline \multicolumn{3}{|l|}{ Karbohidrat } \\
\hline Kurang & 41 & 21,9 \\
\hline Baik & 116 & 59,2 \\
\hline Lebih & 39 & 19,9 \\
\hline Total & 196 & 100,0 \\
\hline \multicolumn{3}{|l|}{ Protein } \\
\hline Kurang & 51 & 26,0 \\
\hline Baik & 76 & 38,8 \\
\hline Lebih & 69 & 35,2 \\
\hline Total & 196 & 100,0 \\
\hline \multicolumn{3}{|l|}{ Lemak } \\
\hline Kurang & 55 & 28,1 \\
\hline Baik & 84 & 42,9 \\
\hline Lebih & 57 & 29,1 \\
\hline Total & 196 & 100,0 \\
\hline
\end{tabular}

Sumber: Data Primer, 2017

2) Status Gizi Siswa

Tabel 2 Distribusi Responden Berdasarkan Status Gizi

\begin{tabular}{|c|c|c|}
\hline Status Gizi Siswa & $\mathrm{n}$ & $\%$ \\
\hline Sangat kurus & 6 & 3,1 \\
\hline Kurus & 67 & 34,2 \\
\hline Normal & 62 & 31,6 \\
\hline Gemuk & 37 & 18,9 \\
\hline Obesitas & 24 & 12,2 \\
\hline Total & 196 & 100,0 \\
\hline
\end{tabular}

Sumber: Data Primer, 2017

3) Hubungan Asupan Zat Gizi Makro dari Sarapan dengan Status Gizi Siswa

Tabel 3 Hubungan Asupan Zat Gizi Makro dari Sarapan dengan Status Gizi Siswa

\begin{tabular}{|c|c|c|c|c|c|c|c|c|c|c|c|c|c|}
\hline \multirow{3}{*}{$\begin{array}{c}\text { Asupan Zat Gizi } \\
\text { Makro dari } \\
\text { Sarapan }\end{array}$} & \multicolumn{10}{|c|}{ Status Gizi } & \multirow{2}{*}{\multicolumn{2}{|c|}{ Jumlah }} & \multirow{3}{*}{$\begin{array}{c}r- \\
\text { hitung } \\
p- \\
- \text { value }\end{array}$} \\
\hline & \multicolumn{2}{|c|}{$\begin{array}{c}\text { Sangat } \\
\text { kurus }\end{array}$} & \multicolumn{2}{|c|}{ Kurus } & \multicolumn{2}{|c|}{ Normal } & \multicolumn{2}{|c|}{ Gemuk } & \multicolumn{2}{|c|}{ Obesitas } & & & \\
\hline & $\mathrm{n}$ & $\%$ & $\mathrm{n}$ & $\%$ & $\mathrm{n}$ & $\%$ & $\mathrm{n}$ & $\%$ & $\mathrm{n}$ & $\%$ & $\mathrm{n}$ & $\%$ & \\
\hline Karbohi Kurang & 5 & 83,3 & 34 & 50,7 & 1 & 1,6 & 1 & 2,7 & 0 & 0,0 & 41 & 20,9 & \\
\hline drat Baik & 1 & 16,7 & 32 & 47,8 & 48 & 77,8 & 23 & 62,2 & 12 & 50,0 & 116 & 59,2 & 0,615 \\
\hline Lebih & 0 & 0,0 & 1 & 1,5 & 13 & 21,0 & 13 & 35,1 & 12 & 50,0 & 39 & 19,9 & 0,000 \\
\hline Jumlah & 6 & 100,0 & 67 & 100,0 & 62 & 100,0 & 37 & 100,0 & 24 & 100,0 & 196 & 100,0 & \\
\hline $\begin{array}{ll}\text { Protein } & \text { Kurang }\end{array}$ & 6 & 100,0 & 38 & 56,7 & 4 & 6,5 & 1 & 2,7 & 2 & 8,3 & 51 & 26,0 & 0,532 \\
\hline Baik & 0 & 0,0 & 21 & 31,3 & 31 & 50,0 & 13 & 35,1 & 11 & 45,8 & 76 & 38,8 & 0,000 \\
\hline
\end{tabular}


Vol. 1 , No. 1 , Januari 2019

\begin{tabular}{|c|c|c|c|c|c|c|c|c|c|c|c|c|c|c|}
\hline \multirow{2}{*}{\multicolumn{2}{|c|}{$\begin{array}{c}\text { Asupan Zat Gizi } \\
\text { Makro dari } \\
\text { Sarapan }\end{array}$}} & \multirow{2}{*}{\multicolumn{2}{|c|}{$\begin{array}{c}\text { Sangat } \\
\text { kurus }\end{array}$}} & \multicolumn{6}{|c|}{ Status Gizi } & \multirow{2}{*}{\multicolumn{2}{|c|}{ Obesitas }} & \multirow{2}{*}{\multicolumn{2}{|c|}{ Ju nlah }} & \multirow{5}{*}{$\begin{array}{c}r- \\
\text { hitung } \\
p- \\
\text { value }\end{array}$} \\
\hline & & & & \multicolumn{2}{|c|}{ Kurus } & \multicolumn{2}{|c|}{ Normal } & \multicolumn{2}{|c|}{ Gemuk } & & & & & \\
\hline & & $\mathrm{n}$ & $\%$ & $\mathrm{n}$ & $\%$ & $\mathrm{n}$ & $\%$ & $\mathrm{n}$ & $\%$ & $\mathrm{n}$ & $\%$ & $\mathrm{n}$ & $\%$ & \\
\hline & Lebih & 0 & 0,0 & 8 & 11,9 & 27 & 43,5 & 23 & 62,2 & 11 & 45,8 & 69 & 35,2 & \\
\hline & Jumlah & 6 & 100,0 & 67 & 100,0 & 62 & 100,0 & 37 & 100,0 & 24 & 100,0 & 196 & 100,0 & \\
\hline Lemak & Kurang & 6 & 100,0 & 44 & 65,7 & 1 & 1,6 & 3 & 8,1 & 1 & 4,2 & 55 & 28,1 & \\
\hline & Baik & 0 & 0,0 & 22 & 32,8 & 37 & 59,7 & 14 & 37,8 & 11 & 45,8 & 84 & 42,9 & 0,635 \\
\hline & Lebih & 0 & 0,0 & 1 & 1,5 & 24 & 38,7 & 20 & 54,1 & 12 & 50,0 & 57 & 29,1 & 0,000 \\
\hline & Jumlah & 6 & 100,0 & 67 & 100,0 & 62 & 100,0 & 37 & 100,0 & 24 & 100,0 & 196 & 100,0 & \\
\hline
\end{tabular}

Sumber: Data Primer, 2017

\subsection{Pembahasan}

Hubungan asupan karbohidrat dengan status gizi siswa (Tabel 3) diperoleh hubungan yang signifikan ( $p$ value $=0,000$ ). Hal ini dikarenakan sebagian besar siswa atau responden yang berstatus gizi normal didapatkan paling banyak mengkonsumsi menu sarapan yang berasal dari sumber karbohidrat, seperti diantaranya: nasi putih, nasi goreng, nasi kuning, roti, sereal, susu, gula dan lain sebagainya. Sedangkan yang berstatus gizi kurang asupan karbohidratnya kurang dari $15 \%$ AKG, dikarenakan siswa-siswa ini banyak dari mereka yang mengkonsumsi menu sarapan berasal dari sumber karbohidrat yang kurang, ada pula diantara mereka yang suka tidak menghabiskan makanannya ataupun makan dengan jumlah porsi yang sedikit.

Karbohidrat adalah sumber penghasil energi paling utama, yang berperan sebagai pembangun bagi kebutuhan sel-sel jaringan tubuh. Setelah semalaman tidur, baiknya makanan diawali dengan pasokan karbohidrat yang cukup, untuk menyeimbangkan berat badan ${ }^{6}$.

Hubungan asupan protein dengan status gizi siswa (Tabel 3) diperoleh hubungan yang signifikan $(p$ value $=0,000)$. Hal ini dikarenakan sebagian besar responden yang memiliki kriteria asupan protein yang baik didapatkan paling banyak mengkonsumsi menu sarapan yang berasal dari sumber protein selain karbohidrat, seperti diantaranya: telur, ikan, daging ayam, susu dan lain sebagainya. Sedangkan yang memiliki status gizi kurus dengan kriteria asupan protein yang kurang dikarenakan banyak diantara mereka kurang mengkonsumsi menu sarapan yang mengandung protein, ataupun kebiasaan yang tidak menghabiskan makanannya.

Protein adalah bagian dari semua sel hidup dan merupakan bagian terbesar tubuh sesudah air. Fungsi utama protein yang tidak dapat digantikan oleh zat gizi lain adalah membangun serta memelihara sel-sel jaringan tubuh ${ }^{7}$. Peran protein dari sarapan sama halnya karbohidrat yang apabila dikonsumsi secara seimbang dapatmempertahankan berat badan.

Hubungan asupan lemak dengan status gizi siswa (Tabel 3) diperoleh hubungan yang signifikan ( $p$ value $=0,000$ ). Hal ini dikarenakan sebagian besar siswa atau responden yang memiliki kriteria asupan lemak yang baik didapatkan paling banyakmengkonsumsi menu sarapan yang mengandung lemak kompleks seperti daging ayam,ikan dan lain sebagainya. Serta cara penyajian makanannya pun disajikan dengan cara digoreng menggunakan minyak. Sedangkan yang kurus dengan kriteria asupan yang masih kurang, kebanyakan dari mereka mengkonsumsi menu sarapan yang kurang mengandung lemak ataupun yang di goreng dengan minyak seperti hanya teh manis saja atau telur yang di rebus.

Lemak adalah sumber energi kedua setelah karbohidrat, memberikan rasa gurih pada makanan sehingga paling digemari oleh anak-anak. Lemak menghasilkan kekenyangan yang lebih lama dari pada karbohidrat dan protein karena waktu untuk mencernanya paling lama ${ }^{8}$. Oleh karena itu apabila siswa-siswa mengkonsumsi zat lemak yang cukup pada waktu sarapan dapat membuat perut terasa kenyang lebih lama sampai dengan waktu istirahat berikutnya. 
Vol. 1 , No. 1 , Januari 2019

Responden yang memiliki status gizi normal, kecukupan gizi pada waktu sarapan tercukupi dengan baik, begitupun siswa yang memiliki status gizi kurus kecukupan gizi pada waktu sarapan masih belum tercukupi dengan baik. Hal ini dibandingkan juga dengan asupan gizi harian yang telah ditinjau peneliti berdasarkan Recall 24 jamkonsumsi makanan yang telah dikonsumsi oleh responden atau siswa selama 3 hari tidak berturut-turut. Jika dilihat dari asupan sarapannya sebagian besar siswa yang berstatus gizi kurang sering melewatkan waktu sarapan dan yang sering sarapan asupan gizinya tidak sesuai, seperti hanya mengkonsumsi teh manis, roti, atau air putih saja. Begitu pula jika ditinjau dari asupan gizi hariannya menunjukkan rata-rata dari mereka mengkonsumsi makanan yang cepat saji atau instan, serta banyak diantara mereka yang makan dengan porsi yang sedikit bahkan melewatkan waktu makan dan lebih memilih makan jajanan yang rendah kalori seperti somay/bakso pentolan.

Siswa yang berstatus gizi normal setelah ditinjau dari hasil Recall 24 jam konsumsi makanannya selama 3 hari yang sama, bila dilihat dari asupan sarapannya baik halnya dibanding yang berstatus gizi kurang. Sebagian besar dari mereka mematuhi waktu makan pagi dengan baik dan asupan makanan dengan sumber gizi yang sesuai, seperti mengkonsumsi nasi goreng, bubur ayam, sereal, susu dan lain sebagainya. Begitupun jika dilihat dari asupan gizi hariannya rata-rata mereka makan dengan porsi makan yang baik, asupan gizi dari makanan yang sesuai serta menu makanan yang cukup lengkap, seperti menu makan yang terdiri dari nasi putih dilengkapi lauk-pauk serta sayuran dan lain sebagainya.

Diantara semua siswa yang telah menjadi responden masih terdapat pula responden yang memiliki kriteria asupan zat gizi makro yang tercukupi namun termasuk pada kategori status gizi yang kurang dari garis normal. Hal ini dikarenakan salah faktor internal dari dalam diri siswa yaitu penyakit infeksi yang sering membuat para siswa ini jatuh sakit. Walaupun asupan gizinya terpenuhi pada waktu tertentu asupan energinya tidak sebanding dengan saat periode sakitnya karena pada umumnya anak-anak saat jatuh sakit jadi sulit untuk mengkonsumsi makanan sehingga kalori yang dihasilkan dipakai sebagai energi untuk melawan sakitnya. Hasil ini sejalan dengan penelitian Pahlevi dan Indarjo (2012) didapatkan bahwa terdapat hubungan antara penyakit infeksi dengan keadaan status gizi siswa di SDN Ngesrep 02 Kota Semarang $(\mathrm{p}=0,001)$. Selain itu terdapat juga siswa yang berkriteria asupan zat gizi makroyang belum tercukupi namun termasuk dalam kategori status gizi yang lebih yaitu gemuk dan obesitas ${ }^{9}$. Hal ini dikarenakan oleh faktor genetik atau riwayat yang diturunkan oleh orangtua, meskipun asupan gizi yang kurang tetapi jika memiliki orangtua yang mengalami obesitas anak tersebut cenderung berisiko obesitas juga. Hasil ini sejalan dengan penelitian Permatasari (2013) pada anak SD di Kota Manado menunjukkan bahwa faktor Ibu dengan obesitas merupakan faktor risiko terjadinya obesitas pada anak $(\mathrm{p}=0,05)^{10}$.

Hasil penelitian ini tidak sejalan dengan penelitian Yunawati (2015) tentang kebiasaan sarapan tidak berhubungan dengan status gizi anak sekolah dasar di Provinsi Nusa Tenggara Timur(p>0,05). Hal ini dapat disebabkan oleh beberapa hal, seperti pengetahuan orang tua, serta kualitas dan kuantitas asupan energi dan protein sarapan yang rendah ${ }^{11}$.

Terdapatnya hubungan asupan zat gizi makro dari sarapan dengan status gizi siswa pada penelitian ini karena terdapat faktor lain sebagai pendorongnya, seperti pendidikan dan pengetahuan gizi anak dari sekolah, kualitas dan kuantitas makanan yang tersedia dirumah, serta aktivitas penjualan makanan di lingkungan sekolah.Adanya variasi status gizi pada siswa kelas VIII MTs Negeri 1 Kota Gorontalo disebabkan oleh berbagai faktor yang merupakan faktor pendorong yaitu faktor internal dan faktor ekseternal. Faktor-faktor yang termasuk dalam faktor internal adalah faktor genetik, utilisasi makanan, penyakit infeksi, aktivitas fisik dan pengetahuan gizi. Sedangkan yang termasuk dalam faktor eksternal adalah faktor pendidikan dan pengetahuan orangtua, budaya, dan kebersihan lingkungan ${ }^{8}$. Faktor-faktor lain yang mendorong status gizi siswa didapatkan pada penelitian yaitu ketersediaan pangan dalam keluarga, kebiasaan makan yang salah serta pengaruh teman sebaya. Selain 
Vol. 1 , No. 1 , Januari 2019

itu keseimbangan zat gizi makanan yang dimakan baik itu di waktu sarapan dan di waktu lain juga sangat mempengaruhi kecukupan gizi anak. Jika status gizi anak baik dan optimal, maka anak cenderung terhindar dari berbagai penyakit yang disebabkan oleh masalah gizi.

\section{KESIMPULAN}

Asupan zat gizi makro dari sarapan siswa sebagian besar berkriteria asupan yang baik yaitu karbohidrat 59,2\%, 38,8\%protein dan lemak 42,9\%.Pengukuran status gizi pada siswa paling banyak yang berstatus gizi kekurusan(37,3\%). Ada hubungan yang signifikan antara asupan zat gizi makro (karbohidrat $\mathrm{p}=0,000$; protein $\mathrm{p}=0,000$; lemak $\mathrm{p}=0,000$ ) dari sarapan dengan status gizi siswa di MTs Negeri 1 Kota Gorontalo. Diharapkan kepada siswa untuk selalu memperhatikan asupan gizi dari makanan yang dikonsumsi khususnya pada saat sarapan sehingga dapat mempertahankan keadaan status gizi yang optimal.

\section{DAFTAR PUSTAKA}

[1] Istiany, A. dan Rusilanti.Gizi Terapan. Jakarta: Remaja Rosdakarya; 2013

[2] Badan Penelitian dan Pengembangan Kesehatan Kementrian Kesehatan RI.Riset Kesehatan Dasar

(Riskesdas 2013). Jakarta : Kementrian Kesehatan Republik Indonesia;2013

[3] Badan Penelitian dan Pengembangan Kesehatan Kementrian Kesehatan RI.Riset Kesehatan Dasar

(Riskesdas 2010). Jakarta : Kementrian Kesehatan Republik Indonesia;2010

[4] Soedibyo, S., dan Gunawan, H. Kebiasaan Sarapan di KalanganAnak Usia Sekolah Dasar di

Poliklinik Umum Departemen Ilmu Kesehatan Anak UI: FKUI;2016

[5] Barasi, M. E.At a Glance. Ilmu Gizi.Jakarta: Erlangga; 2007

[6] Hardinsyah \& Aries M. 2012. Jenis Pangan Sarapan dan Peranannya Dalam Asupan Gizi Harian Anak Usia 6-12 Tahun Di Indonesia. Departmen GiziMasyarakat. IPB.

[7] Proverawati, A dan Kusumawati, A. Ilmu Gizi Untuk Keperawatan dan Gizi Kesehatan.

Yogyakarta : Nuha Medika; 2011

[8] Marmi. Gizi Dalam Kesehatan Reproduksi. Yogyakarta: Pustaka Pelajar; 2013

[9] Pahlevi, A. \& Indarjo, S. 2012. Determinan Status Gizi Pada Siswa Sekolah Dasar. Jurnal Kesmas. UNES.

[10] Permatasari, I. R. Analisis Riwayat Orang Tua Sebagai Faktor Resiko Obesitas Pada Anak SD di Kota Manado. Jurnal Keperawatan. Manado: UNSRAT; 2013

[11] Yunawati, I. Hubungan Kebiasaan Sarapan dengan Status Gizi Anak Sekolah Dasar di Kabupaten Timor Tengah Selatan Provinsi Nusa Tenggara Timur. Tesis. UGM; 2015 